University of Nebraska - Lincoln

DigitalCommons@University of Nebraska - Lincoln

USDA Wildlife Services - Staff Publications

U.S. Department of Agriculture: Animal and Plant Health Inspection Service

2010

\title{
Assessment of Abilities of White-Tailed Deer to Jump Fences
}

Kurt C. Vercauteren

USDA-APHIS-Wildlife Services, kurt.c.vercauteren@usda.gov

Timothy R. Vandeelen

University of Wisconsin

Michael J. Lavelle

USDA/APHIS/WS National Wildlife Research Center, michael.j.lavelle@aphis.usda.gov

Wayne Hall

Wisconsin Department of Natural Resources

Follow this and additional works at: https://digitalcommons.unl.edu/icwdm_usdanwrc

Part of the Life Sciences Commons

Vercauteren, Kurt C.; Vandeelen, Timothy R.; Lavelle, Michael J.; and Hall, Wayne, "Assessment of Abilities of White-Tailed Deer to Jump Fences" (2010). USDA Wildlife Services - Staff Publications. 1342.

https://digitalcommons.unl.edu/icwdm_usdanwrc/1342

This Article is brought to you for free and open access by the U.S. Department of Agriculture: Animal and Plant Health Inspection Service at DigitalCommons@University of Nebraska - Lincoln. It has been accepted for inclusion in USDA Wildlife Services - Staff Publications by an authorized administrator of DigitalCommons@University of Nebraska - Lincoln. 


\title{
Assessment of Abilities of White-Tailed Deer to Jump Fences
}

\begin{abstract}
KURT C. VERCAUTEREN, ${ }^{1}$ United States Department of Agriculture, Animal and Plant Health Inspection Service, Wildife Services, National Wildlife Research Center, Fort Collins, CO 80521-2154, USA

TIMOTHY R. VANDEELEN, Department of Forest and Wildlife Ecology, University of Wisconsin, Madison, WI 53706, USA

MICHAEL J. LAVELLE, United States Department of Agriculture, Animal and Plant Health Inspection Service, Wildlife Services, National Wildlife Research Center, Fort Collins, CO 80521-2154, USA

WAYNE H. HALL, Wisconsin Department of Natural Resources, Wisconsin Rapids, WI 54494, USA

ABSTRACT There is a need for insight into fence heights required for impeding white-tailed deer (Odocoileus virginianus). We evaluated the ability of wild-caught deer to jump progressively taller fences and documented deterrence rates of $0 \%$ for fences $\leq 1.5 \mathrm{~m}$ followed by increasing deterrence rates of $14 \%$ at $1.8 \mathrm{~m}, 85 \%$ at $2.1 \mathrm{~m}$, and $100 \%$ at $2.4 \mathrm{~m}$. We documented $100 \%$ deterrence rates during 5 additional experiments with different deer and the test fence at $2.4 \mathrm{~m}$, a common height of fences at captive deer facilities. Our results will be valuable to those managing spread of wildlife diseases, deer-vehicle collisions, and agricultural damage.
\end{abstract}

KEY WORDS containment, exclusion, fence, jumping, Odocoileus virginianus, white-tailed deer, Wisconsin.

White-tailed deer (Odocoileus virginianus) farms may be sources of disease (e.g., bovine tuberculosis [BTB], chronic wasting disease $[\mathrm{CWD}])$ to free-ranging cervid populations (Miller and Thorne 1993, Rhyan et al. 1995, Demarais et al. 2002); of course, transmission from free-ranging deer to farmed deer is also possible. The principal means to prevent contact and interchange between wild and farmed animals is the use of fencing (Ward et al. 2009). Primary disease concerns focus on fence-line contact (Kaneene et al. 2002; VerCauteren et al. $2007 a, b)$ and ingress or egress of infected animals (Miller and Thorne 1993, Rhyan et al. 1995, Hunter 1996). We found fence-line interactions between farmed and free-ranging deer to be uncommon (VerCauteren et al. 2007b), and rates of ingress or egress undocumented, although known to occur (Wisconsin Department of Natural Resources [WDNR] 2002, VerCauteren et al. 2007b).

The height required to keep deer from jumping a fence has not been quantified. This height is critical for disease management and for prevention of automobile collisions (Feldhamer et al. 1986), aircraft strikes (Dolbeer et al. 2000), and crop damage (VerCauteren et al. 2006a). Literature suggests that deer are capable of jumping 2.32.4-m fences (Falk et al. 1978, Sauer 1984) and that fences $<3 \mathrm{~m}$ are not entirely deer proof (Curtis et al. 1994, Kaneene et al. 2002, VerCauteren et al. 2006b). Our goal was to determine how high a fence must be to prevent jumping by white-tailed deer.

\section{STUDY AREA}

We conducted our study on Sandhill Wildlife Management Area, USA (WMA; $44^{\circ} 19^{\prime} 54^{\prime \prime} \mathrm{N}, 90^{\circ} 9^{\prime} 53^{\prime \prime} \mathrm{W}$ ), managed by the WDNR. Sandhill WMA was located in central Wisconsin's Wood County and was surrounded by a 2.7$\mathrm{m}$ perimeter fence. Available deer range occupied 3,271 ha, of which 1,883 ha was generally flat upland forest, brush,

${ }^{1}$ E-mail: kurt.c.vercauteren@aphis.usda.gov and grass, whereas lowland brush and marsh occupied 1,388 ha (Kubisiak et al. 2001). Sandhill WMA experienced long cold winters and short hot summers with approximately $76 \mathrm{~cm}$ of rain and snow annually (Kubisiak et al. 2001). White-tailed deer at Sandhill WMA were O. v. borealis, the largest subspecies of white-tailed deer, and the subspecies that occurs in south central Wisconsin, USA, where CWD is prevalent and in Michigan and Minnesota, USA, where BTB infects deer populations (Baker 1984). O. v. borealis is also a commonly farmed subspecies.

\section{METHODS}

From February 2006 through January 2008, we captured deer in Sandhill WMA with netted cage traps (VerCauteren et al. 2000), Stevenson box traps (Schemnitz 1996), drop nets (Conner et al. 1987), and rocket nets (Hawkins et al. 1968). We immobilized deer using a combination of Telazol ${ }^{\circledR}(4.4 \mathrm{mg} / \mathrm{kg}$; Fort Dodge Laboratories, Inc., Fort Dodge, IA) and xylazine $\mathrm{HCl}(2.2 \mathrm{mg} / \mathrm{kg}$; AgriLabs, St. Joseph, MI; Kreeger 1996) delivered intramuscularly via hand injection or dart and gas-powered dart projector. We then relocated animals to the experimental pen within Sandhill WMA where we reversed immobilization with tolazoline (3 mg/kg, Tolazine; Lloyd Laboratories, Shenandoah, IA) delivered intravenously $\geq 60 \mathrm{~min}$ after immobilization. To facilitate identification of individuals we marked deer using alphanumerically coded collars made of 10-cm-wide vinyl belting (192 g; Ritchey Manufacturing Co., Brighton, CO). Collars were light and flexible to ensure they would not inhibit movement of deer or cause stress (Moll et al. 2009).

The experimental pen was $2.4 \mathrm{ha}, 270 \mathrm{~m}$ long, and $84 \mathrm{~m}$ wide (Fig. 1), surrounded by a $4.2-\mathrm{m}$ fence consisting of 3.0-m woven wire (Solidlock ${ }^{\circledR}$ Game Fence; Bekaert Corporation, Marietta, GA) topped with $1.2-\mathrm{m}$ polyethylene snow fence (Standard Utility, Snow and Safety Fence; CONWED, Global Netting Solutions, Minneapolis, MN). The test fence, of similar woven wire, bisected the pen and 


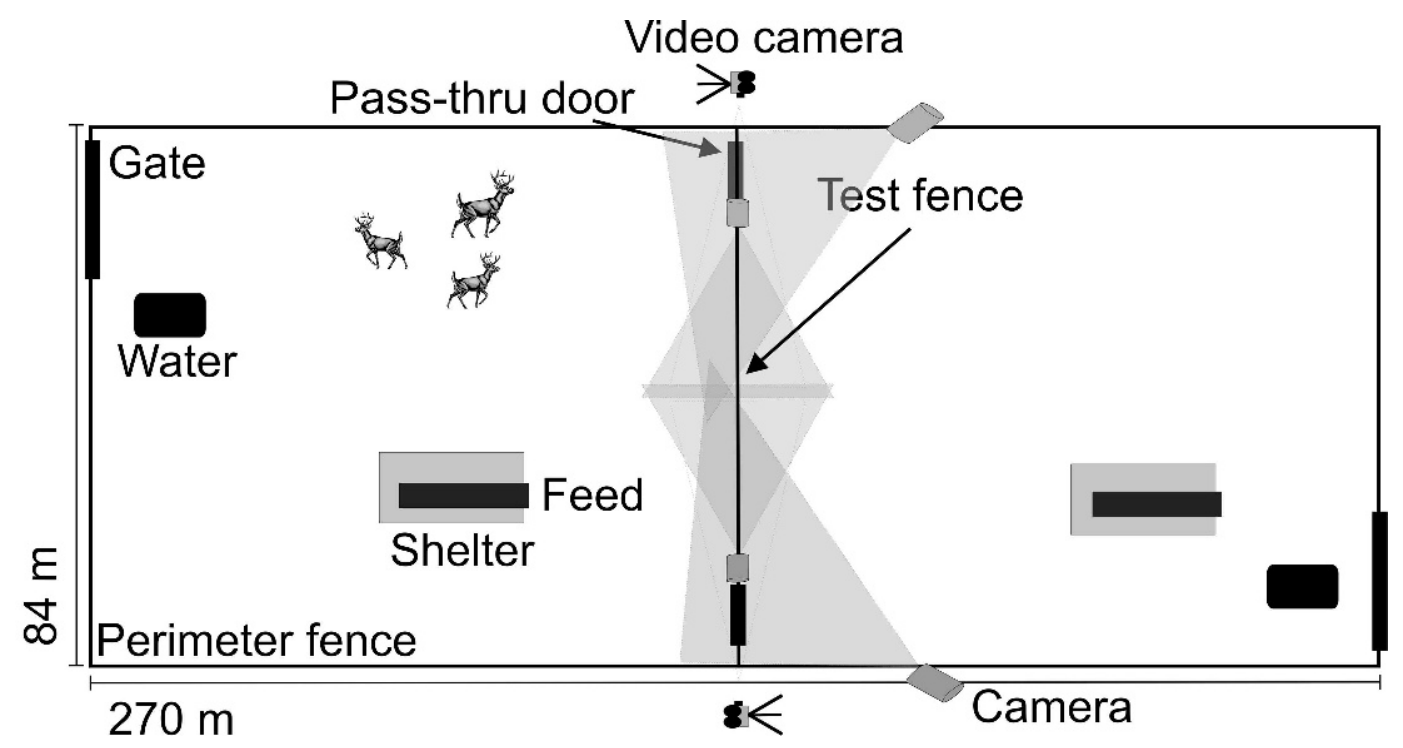

Figure 1. Layout of experimental pen we used to assess ability of white-tailed deer to jump fences of increasing height in central Wisconsin, USA, March 2006-January 2008. The perimeter fence was $4.2 \mathrm{~m}$ high and height of the test fence varied.

we adjusted it to increasing heights as the study progressed. We installed plywood pass-thru doors $(0.9 \mathrm{~m} \times 1.0 \mathrm{~m})$ at each end of the test fence to facilitate herding deer to one side of the pen.

The pen was well vegetated and situated on level sandy soil. We removed trees and shrubs from $50 \mathrm{~m}$ either side of the test fence to eliminate visual and physical obstructions. Vegetation in this area did not exceed $0.2 \mathrm{~m}$ in height during the study. Natural vegetation in the pen provided food and cover, yet we supplemented both. We provided ad libitum access to commercial deer feed (Field-N-Forest Wild Deer Feed; Mills Fleet Farm, Appleton, WI), wholekernel corn, alfalfa hay, and fresh water. We erected a shelter on each side of the test fence to provide shade and protect feed from rain. The Institutional Animal Care and Use Committees of the United States Department of Agriculture/Animal and Plant Health Inspection Service/ Wildlife Services/National Wildlife Research Center (QA1247) and the University of Wisconsin (no. A01186) approved all procedures.

We conducted a series of 6 experiments. The first experiment began with 22 deer (14 Apr 2006) and tested their ability to jump the test fence, which we first set at $0.9 \mathrm{~m}$ and raised $0.3 \mathrm{~m}$ approximately every week until no deer jumped it (ended 14 Jun 2006). The second through sixth experiments (12 Mar 2007, 23 Mar 2007, 10 Apr 2007, 21 Dec 2007, and 9 Jan 2008) provided further testing at the fence height at which all deer in experiment 1 were unable to jump. The number of deer in the latter experiments ranged from 3 to 6 .

At the initiation of each experiment, and each subsequent trial within the first experiment, we allowed deer $\geq 24$ hours to acclimate to the pen and to jump the test fence under their own volition. We termed this the adaptation phase, during which we minimized human activity within the experimental enclosure, only entering to replenish deer feed and water. At the completion of each adaptation phase, we conducted human-induced drives toward the test fence to motivate deer to jump it. Just before conducting drives, we ensured all deer were on the same side of the enclosure by gently herding them all to the same side through the passthru doors at each end of the test fence. We then closed the pass-thru doors, exited the now empty side of the pen, and went to the opposite end of the pen to initiate the drive. We aligned 3 people along the perimeter fence at the far end of the pen and slowly approached the deer, driving them toward the test fence. We concluded drives when all of the deer jumped the test fence or demonstrated they were incapable or unwilling to jump.

To monitor activity and collect data on deer jumping the test fence, we used 4 color cameras (Panasonic Super Dynamic II, WV-CW374; Matsushita Electric Industrial Co., Ltd., Osaka, Japan), each focused on roughly $25 \%$ of the test fence (Fig. 1). We paired cameras with 940-nm infrared illuminators (IR13; Super Circuits, Austin, TX) to optimize quality of footage collected during darkness. We connected this system to a remote computer outfitted with a video capture card system (SVG 6-8; Super Circuits). When the system detected a change in imagery (e.g., motion), it saved footage from 5 minutes before the change until motion ceased. During drives, we also collected footage with video cameras $\left(\right.$ Sony ${ }^{\circledR}$ Handycam DCR-TRV350; Sony Corporation, Tokyo, Japan) mounted on tripods outside the perimeter fence and aimed along the test fence.

Throughout each adaptation phase and drive, we recorded time lapsed, number of deer involved, number that jumped the fence, and number of failed attempts to jump the fence. For experiment 1, we assumed deer that did not jump the test fence at a given height could not jump it at the subsequent height. Thus, we used a destructive sampling method and released deer that did not jump the fence during a trial. We conducted a second trial at $2.1 \mathrm{~m}$ to increase our confidence in the results of the initial 2.1-m trial. Because trials were not independent, we used descriptive statistics to 


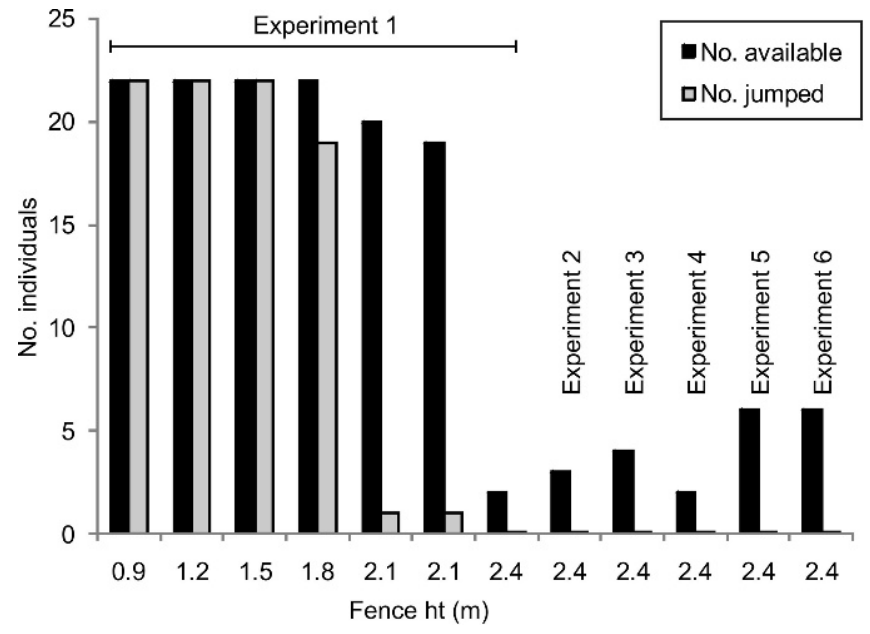

Figure 2. Number of deer available and successful in jumping the test fence during drives in an assessment of ability of white-tailed deer to jump fences in central Wisconsin, USA, March 2006-January 2008.

describe deterrence rates during experiment 1 . We also calculated a jumping rate (jumps/hr) during adaptation phases to demonstrate willingness to jump differing heights under minimal motivation. For experiments 2-6, we estimated efficacy or deterrence rate (binomial proportion, where we defined deterrence as 0 deer/group jumped fence) and $95 \%$ confidence intervals using the EXACT statement in the FREQ procedure of SAS (SAS Institute, Cary, NC; Collett 1991), assuming groups were experimental units.

\section{RESULTS}

Experiment 1 (14 Apr-14 Jun 2006) included 22 deer (11 F [9 ad, 2 yearlings] and $11 \mathrm{M}$ [7 ad, 4 yearlings]). We conducted 7 trials with these deer as one group (Fig. 2). We began with the test fence at $0.9 \mathrm{~m}$ and progressed to $2.4 \mathrm{~m}$ over a period of 9 weeks. All deer in experiment 1 successfully jumped the test fence when it was at $0.9 \mathrm{~m}$, $1.2 \mathrm{~m}$, and $1.5 \mathrm{~m}$. Of 22 deer, 19 jumped the test fence when it was $1.8 \mathrm{~m}$ high on 10 May. There was only one deer of 21 deer (a yearling $\mathrm{M}$ ) that jumped during the 2.1-m drive on 24 May. To be more confident in this result, we retained all 21 deer and repeated the 2.1-m drive the following week. During the second drive at $2.1 \mathrm{~m}$, a yearling female jumped. Neither of these deer jumped the test fence when it was increased to $2.4 \mathrm{~m}$. Upon viewing footage from the second 2.1-m adaptation phase, we documented that an adult male had also jumped the test fence. Unfortunately, due to our destructive sampling design, we had released this individual before the 2.4-m trial when it did not jump during either drive with the fence at $2.1 \mathrm{~m}$. During the $1.8-2.1-\mathrm{m}$ drives, there were numerous failed attempts, although it was not possible to identify individuals involved. It was not apparent that any deer attempting to jump during drives sustained injuries that may have precluded them from making further attempts.

Number of jumps/24 hours recorded during adaptation phases steadily declined throughout experiment 1 as follows: 17.2 at $0.9 \mathrm{~m}, 14.2$ at $1.2 \mathrm{~m}, 10$ at $1.5 \mathrm{~m}, 1.3$ at $1.8 \mathrm{~m}, 0.1$ at
$2.1 \mathrm{~m}$, and 0 at $2.4 \mathrm{~m}$. Fences $0.9-1.5 \mathrm{~m}$ high did little to impede deer during drives in experiment 1 , as indicated by deterrence rates of $0 \%$ (22/22 jumped). At $1.8 \mathrm{~m}, 19$ of 22 deer jumped, resulting in a $14 \%$ deterrence rate. Of 20 deer, 2 deer were successful during drives and one deer during the adaptation phase at $2.1 \mathrm{~m}$, resulting in a combined deterrence rate of $85 \%$.

We conducted experiments 2-6 to gather more data with the test fence at $2.4 \mathrm{~m}$, the height at which no deer jumped during experiment 1 . For these experiments, we trapped 21 additional deer (16 M [11 ad, 5 yearlings] and $5 \mathrm{ad} \mathrm{F}$ ) and conducted human-induced drives on 12 March 2007, 23 March 2007, 10 April 2007, 21 December 2007, and 9 January 2008. Each experiment included 3-6 deer, and none jumped the fence during adaptation phases or drives during any of these experiments (deterrence rate $=1.00,95 \% \mathrm{CI}=$ 0.48-1.00). During these experiments, where we did not progressively raise the fence like in experiment 1 , there were $\leq 6$ failed attempts/drive, and deer ran into the test fence but did not attempt to jump it.

\section{DISCUSSION}

The decline in number of jumps/24 hours during adaptation phases in experiment 1 demonstrated increasing efficacy of each fence height. During drives at lower heights $(\leq 1.5 \mathrm{~m})$, we observed deer typically moving and reacting as a herd and when a lead animal jumped the fence others followed. Above the 1.5$\mathrm{m}$ height deer acted independently, perhaps due to individual physical capabilities or excitability. Individuals would approach and jump, or attempt to jump, more sporadically and not as a cohesive herd. This was especially evident during experiment 1 at the $2.1-\mathrm{m}$ height when 3 successful jumps involved 3 deer. On each occasion, only one individual jumped although all 3 capable individuals were present.

We assumed deer that were physically capable of jumping a particular height would do so when motivated during a drive. Relative to this, in experiment 1 we released individual deer if they did not jump the test fence during a trial so that they were not subjected to more stress and an even higher fence. Our assumption proved wrong because video footage from the adaptation phase of the second 2.1$\mathrm{m}$ trial documented an adult male jumping the fence. Because this individual did not jump the test fence during either 2.1-m drive, we released it before the 2.4-m trial so we do not know whether it had the ability to clear a $2.4-\mathrm{m}$ fence. We were surprised by the lack of deer jumping the 2.4-m fence, so post hoc we surveyed $>150$ wildlife biologists who routinely observe deer in proximity to fences and found 6 who had witnessed deer jump fences $\geq 2.4 \mathrm{~m}$.

Seasonal physiology and physical condition could influence the jumping ability of deer. We physically examined, observed, and deemed each deer healthy before including it in our study. However, stage of pregnancy could affect the ability of female deer to jump fences, and experiments 1-4 took place when pregnant females were more than halfway through parturition. Therefore, jumping rates could have been biased low for females in our study. 
We incrementally increased height of the test fence in experiment 1 because we assumed that deer accustomed to jumping, and progressively stimulated to jump higher, would effectively represent the best jumpers in an overall population. We also assumed that a fence that deters deer with experience jumping fences would deter most deer in a population. Deer in our study, progressively trained or not, did not jump a 2.4$\mathrm{m}$ fence. However, the ability of deer to jump fences should be evaluated further using other experimental designs and with other subspecies of white-tailed deer.

\section{Management Implications}

Wildlife management agencies, departments of agriculture, and the farmed cervid industry need reliable information from which to establish fence requirements. Deer in our study would not jump a 2.4-m fence, suggesting that a 2.4$\mathrm{m}$ fence will contain or exclude most white-tailed deer under conditions similar to our study. However, incidental observations of deer jumping $>2.4-\mathrm{m}$ fences indicate that a well constructed and maintained fence $>2.4 \mathrm{~m}$ would be justified if $100 \%$ deterrence is required.

\section{Acknowledgments}

We thank C. Benell, P. Burke, J. Fischer, J. Gilsdorf, E. Heilhecker, D. MacFarland, K. Malcolm, N. Seward, D. Storm, R. Walrath, and M. Watt for assistance in the field. We thank G. Phillips for statistical assistance. We thank S. Demarais, K. Miller, and an anonymous referee for thoughtful reviews and aid in improving the manuscript. Permission and assistance granted by the WDNR, especially staff at Sandhill WMA, was invaluable. We also thank the Bekaert Corporation for donating fencing. Mention of companies or commercial products does not imply recommendation or endorsement by the United States Department of Agriculture. We mentioned product names solely to report factually on available data and to provide specific information.

\section{LITERATURE CITED}

Baker, R. H. 1984. Origin, classification and distribution. Pages 1-18 in L. K. Halls, editor. White-tailed deer: ecology and management. Stackpole, Harrisburg, Pennsylvania, USA.

Collett, D. 1991. Modelling binary data. Chapman \& Hall, London, United Kingdom.

Conner, M. C., E. C. Soutiere, and R. A. Lancia. 1987. Drop-netting deer: costs and incidence of capture myopathy. Wildlife Society Bulletin 15:434-438.

Curtis, P. D., M. J. Fargione, and M. E. Richmond. 1994. Preventing deer damage with barrier, electrical, and behavioral fencing systems. Proceedings of the Vertebrate Pest Conference 16:223-227.

Demarais, S., R. W. DeYoung, L. J. Lyon, E. S. Williams, S. J. Williamson, and G. J. Wolfe. 2002. Biological and social issues related to confinement of wild ungulates. Wildlife Society Technical Review 02-3.

Dolbeer, R. A., S. E. Wright, and E. C. Cleary. 2000. Ranking the hazard level of wildlife species to aviation. Wildlife Society Bulletin 28:372-378.

Falk, N. W., H. B. Graves, and E. D. Bellis. 1978. Highway right-of-way fences as deer deterrents. Journal of Wildlife Management 42:646-650.
Feldhamer, G. A., J. E. Gates, D. M. Harman, A. J. Loranger, and K. R. Dixon. 1986. Effects of interstate highway fencing on white-tailed deer activity. Journal of Wildlife Management 50:497-503.

Hawkins, R. E., L. D. Montgomery, and G. G. Montgomery. 1968. Cannon-netting deer. Journal of Wildlife Management 32:191-195.

Hunter, D. L. 1996. Tuberculosis in free-ranging, semi free-ranging and captive cervids. Revue Scientifique et Technique, Office International des Epizooties 15:171-181.

Kaneene, J. B., C. S. Bruning-Fann, L. M. Granger, R. Miller, and B. A. Porter-Spalding. 2002. Environmental and farm management factors associated with tuberculosis on cattle farms in northeastern Michigan. Journal of Veterinary Medical Association 221:837-842.

Kreeger, T. J., editor. 1996. Handbook of wildlife chemical immobilization. Wildlife Pharmaceuticals, Fort Collins, Colorado, USA.

Kubisiak, J. F., K. R. McCaffery, W. A. Creed, T. A. Heberlein, R. C. Bishop, and R. E. Rolley. 2001. Sandhill whitetails: providing new perspective for deer management. Wisconsin Department of Natural Resources, Madison, USA.

Miller, M. W., and E. T. Thorne. 1993. Captive cervids as potential sources of disease for North America's wild cervid populations: avenues, implications and preventative management. Transactions of the North American Wildlife and Natural Resources Conference 58:460-467.

Moll, R. J., J. J. Millspaugh, J. Beringer, J. Sartell, R. Woods, and K. C. VerCauteren. 2009. Physiological stress response of captive white-tailed deer to video collars. Journal of Wildlife Management 73:609-614.

Rhyan, J., K. Aune, B. Hood, R. Clarke, J. Payeur, J. Jarnagin, and L. Stackhouse. 1995. Bovine tuberculosis in a free-ranging mule deer (Odocoileus hemionus) from Montana. Journal of Wildlife Diseases 31:432-435.

Sauer, P. R. 1984. Physical characteristics. Pages 73-90 in L. K. Halls, editor. White-tailed deer: ecology and management. Stackpole, Harrisburg, Pennsylvania, USA.

Schemnitz, S. D. 1996. Capturing and handling wild animals. Pages 106124 in T. A. Bookhout, editor. Research and management techniques for wildlife and habitats. Allen Press, Lawrence, Kansas, USA.

VerCauteren, K. C., J. Beringer, and S. E. Hygnstrom. 2000. Netted-cage traps for white-tailed deer. Pages 155-164 in G. Proulx, editor. Mammal trapping. Alpha Wildlife Research and Management, Sherwood Park, Alberta, Canada.

VerCauteren, K. C., M. J. Lavelle, and S. Hygnstrom. 2006a. A simulation model for determining cost-effectiveness of fences for reducing deer damage. Wildlife Society Bulletin 34:16-22.

VerCauteren, K. C., M. J. Lavelle, and S. Hygnstrom. 2006b. Fences and deer-damage management: a review of designs and efficacy. Wildlife Society Bulletin 34:191-200.

VerCauteren, K. C., M. J. Lavelle, N. W. Seward, J. W. Fischer, and G. E. Phillips. 2007a. Fence-line contact between wild and farmed cervids in Colorado: potential for disease transmission. Journal of Wildlife Management 71:1594-1602.

VerCauteren, K. C., M. J. Lavelle, N. W. Seward, J. W. Fischer, and G. E. Phillips. 2007b. Fence-line contact between wild and farmed white-tailed deer in Michigan: potential for disease transmission. Journal of Wildlife Management 71:1603-1606.

Ward, A. I., K. C. VerCauteren, W. D. Walter, E. Gilot-Fromont, S. Rossi, G. Edwards-Jones, M. S. Lambert, M. R. Hutchings, and R. J. Delahay. 2009. Options for the control of disease 3: targeting the environment. Pages 147-168 in R. J. Delahay, G. C. Smith, and M. R. Hutchings, editors. Management of disease in wild mammals. Springer, Tokyo, Japan.

Wisconsin Department of Natural Resources [WDNR]. 2002. Summary of a statewide audit and inspection of Wisconsin's captive whitetail deer farms. <http://www.cwd-info.org/pdf/DeerFarmAudit.pdf $>$. Accessed 10 Mar 2010.

Associate Editor: Demarais. 